\title{
Displaced: A Proposal for International Law to Protect Refugees, Migrants, and States
}

\section{Citation}

Goldenziel, Jill I. 2016. Displaced: A Proposal for International Law to Protect Refugees, Migrants, and States. Berkeley Journal of International Law (BJIL). Forthcoming.

\section{Permanent link}

http://nrs.harvard.edu/urn-3:HUL.InstRepos:27692581

\section{Terms of Use}

This article was downloaded from Harvard University's DASH repository, and is made available under the terms and conditions applicable to Other Posted Material, as set forth at http:// nrs.harvard.edu/urn-3:HUL.InstRepos:dash.current.terms-of-use\#LAA

\section{Share Your Story}

The Harvard community has made this article openly available.

Please share how this access benefits you. Submit a story.

\section{Accessibility}


***DRAFT. DO NOT CITE WITHOUT PERMISSION.***

\title{
DISPLACED: \\ A PROPOSAL FOR INTERNATIONAL LAW TO PROTECT REFUGEES, MIGRANTS, AND STATES
}

\author{
(forthcoming, Berkeley Journal of International Law, 2016)
}

Jill I. Goldenziel ${ }^{*}$

\begin{abstract}
How can international law better protect both international security and the human rights of people fleeing violence? International refugee law protects only the refugees: those fleeing across borders due to a well-founded persecution on the basis of race, religion, nationality, political opinion, or membership in a particular social group. The world's other 42.3 million people displaced by violence have few protections under international law. This article proposes and sketches new international law to address this crucial human rights problem. I argue that a new Displaced Persons Convention to protect people fleeing violent conflict is needed to supplement the 1951 Refugee Convention. The Refugee Convention must be preserved because of the critical protections it provides for the rights of minorities and political dissidents. Adding a new Displaced Persons Convention would better protect the human rights of individuals fleeing violent conflict and state failure, further state interests, and improve international security.
\end{abstract}

\footnotetext{
* Associate Professor of International Law and International Relations (incoming), Marine Corps University Command and Staff College; Research Fellow, Harvard Kennedy School, International Security Program, Belfer Center for Science and International Affairs; Senior Fellow, Fox Leadership Program, University of Pennsylvania. Ph.D., Government, Harvard University; A.M., Government, Harvard University; J.D., New York University School of Law; A.B., Princeton University. Thanks to Susan Akram, Noah Feldman, Rotem Giladi, James Hathaway, James Loeffler, Stanley Katz, Itamar Mann, Michael Pine, Mira Siegelberg, Robert Sloane, Mark Tushnet, and participants in the Boston University School of Law Faculty Workshop, the American Law and Religion Workshop, and the University of Maryland Junior Faculty Workshop. This article was selected for presentation at the "New Voices in International Law" Panel of the 2015 Annual Meeting of the American Society of International Law.
} 


\section{INTRODUCTION}

International law must be reformed to better protect people fleeing violent conflict and persecution. Doctrinal incoherence in this area comes at the cost of human life. Every day, desperate people risk their lives to flee horrific circumstances based on the misperception that they will receive refugee status and resettlement elsewhere. ${ }^{1}$ Instead, many face maltreatment and the threat of being returned to war zones. Among people fleeing from violence across international borders, international law protects only refugees: those who have fled persecution on the basis of race, religion, national origin, political opinion or membership in a particular social group. Refugees are eligible for international legal protection. All others may be legally thrown back into the horrors from which they came.

Beyond human rights implications, lack of relevant international law to protect people fleeing violence ${ }^{2}$ has tremendous consequences for states. International and domestic legal and humanitarian infrastructures are straining under the sheer numbers of migrants seeking assistance. Migrants constantly seek to obtain international refugee status or protection under domestic asylum regimes, overwhelming even the most developed legal systems. In 2014 and 2015, the European Union struggled to respond to 1 million migrants landing on their shores and illegally entering their borders, and states' resulting squabbles threatened to tear the Union apart. In 2014, tens of thousands of unaccompanied minors fled violent conditions in Central America to seek asylum in the U.S. Upon their arrival, the Department of Homeland Security struggled to find enough lawyers and aid workers to meet their needs, amidst highly politicized debate over whether they should be granted legal status as "refugees" or deported as illegal "migrants."

How can international law better protect both international security and the human rights of people fleeing violence and persecution? This article sketches a framework for new international law to address this

\footnotetext{
${ }^{1}$ See, e.g., Luke Mogelson, The Impossible Refugee BoAt Lift to Christmas ISLAND, NEW YORK TIMES (Nov. 15, 2013) http://www.nytimes.com/2013/11/17/magazine/the-impossible-refugee-boat-lift-tochristmas-island.html?pagewanted=all.

${ }^{2}$ This article uses the term "violence" as shorthand for "violent conflict," which may include war, armed conflict, civil war, or generalized violence that may fall short of any legal definition of war. A discussion of the relationship between other forms of violence, such as domestic violence, and protections for refugees or displaced people lies beyond the scope of this article.

${ }^{3}$ See Frances Robles, Fleeing Gangs, Children Head to U.S. Border, New York TIMES (July 9, 2014) http://www.nytimes.com/2014/07/10/world/americas/fleeing-gangschildren-head-to-us-border.html.
} 
crucial human rights problem. I argue that a new Displaced Persons Convention to protect people fleeing violent conflict is needed to supplement existing international refugee law. The 1951 Refugee Convention must be preserved because of the critical protections it provides for the rights of minorities and political dissidents. Adding a new Displaced Persons Convention would ameliorate the human rights violations and security concerns caused by lack of legal protections for individuals fleeing violent conflict and state failure.

A Displaced Persons Convention would provide legal protection for individuals who have fled violent events deemed by the international community to threaten international peace and security. These reforms would better serve all of those fleeing violence and persecution, as well as states, by clarifying which migrants are eligible for international legal protection. It would also buttress other major goals of international human rights law, such as religious freedom, freedom of expression, and protection against torture and racial discrimination. ${ }^{4}$

A Displaced Persons Convention presents a normative and practical solution to protect people fleeing violent conflict. It is both realist in its goal of protecting state interests and liberal in its appeal for an international legal solution to improve international peace, security, and human rights. It addresses competing moral claims between preserving rights for persecuted refugees, protecting those fleeing from war and conflict, and assisting those seeking relief from vicissitudes of fortune, such as poverty, famine, and climate change. The improved doctrinal clarity would help shape the behavior of both states and individuals in the international system and promote a stronger, less politicized, legal framework for protecting human rights.

\section{Why Refugee Law Fails to Protect Displaced Persons}

The failings of International Refugee Law to protect people displaced by violence are easily highlighted by the stories of Iraqis whom I interviewed in Jordan in 2009. I soon discovered that many U.N.-registered refugees were not legally refugees at all. One former Iraqi army general, whom I will call Hamdan, fled to Jordan in 2005 after his sons' lives were threatened because of their Sabean religion. ${ }^{5}$ Sabeans are an ancient

\footnotetext{
4 Convention on the Elimination of Racial Discrimination, Dec. 21, 1965, 660 U.N.T.S., 195; International Covenant on Civil and Political Rights, Dec. 16, 1966, 999 U.N.T.S. 171, Art. 18.

5 Anonymous Iraqi registered with UNHCR, interview with Author, August 2009 (names and identifying details have been modified to protect the interviewees).
} 
religious sect whose presence in Iraq is now almost non-existent, due to rampant persecution and flight after the U.S. invasion and the ensuing civil war. Hamdan spent years waiting to register with UNHCR, which did not have a program dedicated to assisting Iraqis in 2005, and was not registering Iraqis for resettlement at the time. ${ }^{6}$ After years waiting for UNHCR to register and then process his resettlement claim, Australia finally agreed to resettle Hamdan. While his final approval was pending, his savings ran out, and he relied on charities for his daily bread. Hamdan could not venture out at night for fear of violent harassment. Although his was a clear-cut case for receiving refugee status under the 1951 Convention, and despite his vulnerable status in Jordan, he was stuck in a backlog in an overwhelmed resettlement system clogged with submissions of Iraqis who did not meet the Convention definition.

Another Iraqi school administrator, whom I will call Mohammed, fled for his life after militias accused him of helping American forces simply for trying to reopen Baghdadi schools. ${ }^{7}$ He registered as a refugee with UNHCR in 2007 and applied for resettlement. After years of waiting, he learned that no country would resettle him since he did not meet the international legal criteria for refugee status. He was a Sunni Muslim, and could not prove the identity of the militias that threatened him, nor could he prove that they did so on the basis of religion. His situation was not considered particularly vulnerable by UNHCR, since he was living in the Sunni-majority country of Jordan. He, too, lived in poverty, with no future in sight, and feared every day that the Jordanian security forces would send him back to Iraq.

The stories of these Iraqis illustrate how international refugee law has failed, and why new international law is needed to protect people fleeing violent conflict. Victims of religious persecution, like Hamdan, can claim refugee status under international law. However, they are denied the full protection to which they are legally entitled and wait years for resettlement, caught in a backlog caused by UNHCR's efforts to process all those fleeing conflict. Meanwhile, all those who have fled war, like Mohammed, are called "refugees" by UNHCR. However, Mohammedand most others who have fled war zones like Iraq, Syria, and Afghanistan - stand no chance of meeting strict standards for asylum abroad. These people live in constant fear of sudden expulsion. Mass deportations to war-torn Syria or Afghanistan might be inhumane, but would be perfectly legal.

6 See generally Jill I. Goldenziel, Regulating Human Rights: International Organizations, Flexible Standards, and International Refugee Law, 14 CHI. J. INT'L. L. 453-702 (2014).

${ }^{7}$ Anonymous Iraqi 2 registered with UNHCR, interview with Author, August 2009. 
Like Mohammed, most people fleeing war and conflict do not legally qualify as refugees. People who are fleeing generalized violence may be in circumstances just as dire as those persecuted based on race, religion, nationality, political opinion, or membership in a particular social group, but they are not refugees under international law, and are not eligible for asylum in most states. Of the 60 million people of concern to the U.N. Refugee Agency (the Office of the U.N. High Commissioner for Refugees, or UNHCR), the agency classified only 13.7 million as refugees in 2015. Most of the other 46.3 million people fleeing war and violent conflict-a number larger than the population of $85 \%$ of the countries in the worldhave little to no protection under international law.

\section{A. Law Designed for a Different World}

International refugee law was simply not designed to deal with the endless civil war and state failures at the root of today's global displacement. It was made to protect discrete flows of persecuted minorities and dissidents who could be quickly absorbed by states. In modern times, states codified age-old commitments to protecting minority rights in the 1951 Refugee Convention. This author details the history of the Convention, and the historical concept of refugee protection in international law more generally, in a companion article. ${ }^{8}$

In brief, the 1951 Refugee Convention was created in the wake of World War II, when millions were displaced throughout Europe, a humanitarian disaster that threatened to cause further strife. The nascent U.N. needed solutions to protect, resettle, and guarantee the rights of displaced people who could not return to their countries of origin. The U.N. was simultaneously involved in a broader project of creating international human rights law as a way to entrench the world's collective cry of "never again" after the atrocities of the Holocaust.

The Convention that emerged was eventually signed by 143 of the U.N.'s 191 members. The Convention's core provision, that a refugee cannot be returned to a place where her life will be endangered (known as "non-refoulement"), is considered binding on every state, not just Convention signatories. The Convention also obligates states to provide an array of services to refugees, including the right to work, to housing, and access to courts.

\footnotetext{
${ }^{8}$ Jill I. Goldenziel, The Curse of the Nation-State: Refugees, Migration, and Security in International Law _ ARIZ. ST. L.J. _ (2016).
} 


\section{B. Refugee Flows Are Not What They Used to Be}

The end of the Cold War led to a rise in civil conflict that was unforeseen by the drafters of the 1951 Refugee Convention. Today's refugees are not primarily European, scattered throughout their own continent. They are not awaiting orderly processing in European camps, relatively peacefully, as they were after World War II. Nor are they trickling slowly across borders, as they have throughout much of history. Instead, it is now commonplace for thousands of people fleeing both war and persecution to spill over borders within hours or days. Refugees may flee not just to nearby countries, but find smugglers to carry them halfway around the world.

Changes in the nature of refugee flows became especially pronounced in the 1990s. In April 1991, fearing reprisals from Saddam Hussein's regime after a U.S.-encouraged Kurdish uprising after the First Gulf War, 1.3 million people fled Northern Iraq for Iran over a three-week period. Simultaneously, 400,000 mostly Kurdish Iraqis fled Northern Iraq for Turkey, which promptly closed its borders. 1 million Rwandans fled into Zaire in July 1994 alone. On April 1, 1999, after Serbia rejected Kosovo's autonomy, 25,000 Kosovar Albanians took six trains to Macedonia. In all of these places, economic migrants, finding their business prospects destroyed by war or seeking to flee poverty, easily joined the throngs.

The 1951 Refugee Convention is unequipped for such a massive change in forced migration. The Convention has no provisions for dealing with massive, mixed flows of refugees and migrants, and no provisions for states to share in the burden of assisting them. Under the Convention, a refugee has the right to seek asylum, but no state has the legal obligation to grant it. When mixed flows occur, states are required not to refoul anyone who is seeking international protection while his claim is being processed. A host state thus has a legal obligation to protect members of a mass influx from refoulement, at least temporarily, while the international community has no obligation to share the burden.

Moreover, most people who have fled violence and persecution are hosted by the world's poorest states. Most reside in the Middle East and Africa, where many states have not signed the 1951 Refugee Convention, where asylum systems may not exist, and where the rule of law is often weak. For these reasons, most experts agree that the 1951 Refugee Convention has become irrelevant for the protection of most people fleeing persecution and violence today.

\section{The Politicization of Refugee Assistance}

Since the 1951 Refugee Convention has become less useful, refugee 
protections have been increasingly less legalized over time. UNHCR has largely become a humanitarian aid organization, far from its original function of administering international refugee law and providing legal protections to refugees. ${ }^{9}$ Since the end of the Cold War, the agency has focused more of its budget and organizational priorities on operations and away from legal protection. The agency now strives to serve people displaced by war and conflict as well as 1951 Convention Refugees, which has been quite controversial. One senior protection officer explained to me that "refugee protection means something specific" under international law, and it is eroded each time UNHCR waters it down to aid new categories of people. ${ }^{10}$ However, others within the organization believe the shift in focus from legal protections of refugees to humanitarian aid enables them to assist more people. As a Senior Adviser to the High Commissioner explained to me in 2010, while international law underpins the agency's work, it is often better to get things done rather than "banging the bible." 11

The agency has extended its operations far beyond those specified in its Statute or the Convention. As need has arisen, the U.N. Secretary General has designated additional people to fall within UNHCR's "persons of concern," including select groups of internally displaced people and victims of natural disasters.

Without relevant law to guide it, UNHCR's work has become increasingly politicized. After a number of budgetary crises, UNHCR has survived by making itself an agent of the world's major powers. ${ }^{12}$ The agency's mandate must be regularly renewed by the U.N. Because the agency receives between $93 \%$ of its budget from donors, and $86 \%$ from individual states, it is almost completely dependent on individual donor countries for its survival. The $7 \%$ of its budget that comes directly from the U.N. mostly pays for overhead. To continue its existence, UNHCR must appear responsive and accountable to the whims of its donors.

UNHCR is especially dependent on the U.S. for funding. The U.S. has consistently been the UNHCR's single largest donor, typically funding about $30 \%$ of UNHCR's budget, and currently funding 39\%. The European Commission, its member states, and Japan typically account for most of the remainder of the budget. The U.S. and EC exclusively earmark their contributions to UNHCR to ensure that the agency serves their foreign

\footnotetext{
${ }^{9}$ Gil Loescher, UNHCR AND World Politics: A Perilous Path, (2001), at 80.

${ }^{10}$ Interview with Petros Mastakis, Protection Officer, UNHCR-Syria, in Damascus, Syria, (Jan. 6, 2010).

11 Interview with Jose Riera, Senior Policy Adviser to the High Commissioner, UNHCR, in Geneva, Switz. (June 18, 2010).

${ }^{12}$ On agency in international organizations, see generally DARREN G. HAWKINS ET AL., DELEGATION AND AGENCY IN INTERNATIONAL ORGANIZATIONS (2006).
} 
policy goals. In 2014 , only $15 \%$ of the agency's total contributions were unearmarked. The agency's operations, then, are a function of the political interests of the major powers that fund it.

De-legalization of the refugee regime has meant increasing politicization of refugee assistance. UNHCR has increasingly acted at the behest of the wealthy states that provide its funding. ${ }^{13}$ To give but a few examples, the agency expanded its mission for the first time to include internally displaced people in the early 1990s to assist nearly all of those displaced due to the disintegration of the former Yugoslavia. This radical expansion of the agency's mission was done at the behest of European powers that wished to keep Muslim immigrants from entering into Europe. ${ }^{14}$ After the U.S. invasion of Iraq in 2003, a "prima facie" refugee regime was adopted to term nearly all Iraqis who had fled to neighboring countries as "refugees." "This allowed them to receive legal and humanitarian assistance from UNHCR and its partners, regardless of whether they met the 1951 Convention definition of refugee. Backed by U.S. and EC funding, UNHCR then provided all displaced Iraqis with more assistance, in terms of dollars per refugee, than any of its other refugees throughout the globe.

\section{The World Closes Its Gates}

Meanwhile, increasingly restrictive domestic asylum regimes, particularly in the West, have narrowed the reach of the 1951 Convention. States have defined persecution narrowly, requiring refugees to prove a specific fear of persecution, or to return to dangerous conditions in their countries of origin to provide identity documents in order to be resettled. ${ }^{16}$ Elsewhere, states have refused to winnow refugees from "mixed flows" containing refugees and migrants, instead sending all would-be asylum-

\footnotetext{
${ }^{13}$ On how the agency has expanded and contracted the definition of refugee to serve the interests of its donor states, particularly the U.S. See Jill Goldenziel, supra note 15. (documenting expansion of the term refugee to encompass most Iraqis fleeing after the U.S. invasion of 2003); JiLl Goldenziel, DisPlaced: RefugeEs, INTERNATIONAL LAW, AND U.S. FOREIGN POLICY (forthcoming).

${ }_{15}^{14}$ LOESCHER, supra note 9.

15 See generally Jill I. Goldenziel, Regulating Human Rights: International Organizations, Flexible Standards, and International Refugee Law, 14 CHI. J. INT'L. L. 453-702 (2014).

${ }^{16}$ For example, Iraqi refugees in 2006 and 2007 were required to return to Iraq to retrieve identity documents, often at great personal risk given pervasive civil conflict and rampant persecution on the basis of religion.
} 
seekers back home. ${ }^{17}$ In the 2000s, the European Union revamped its asylum regime with a series of laws designed to discourage migration by sending asylum-seekers back to their original country of entry within Europe, and building massive detention centers in Italy and Greece, the most frequent points of entry, to house them while they ostensibly await processing. In 2004, the European Union also created a new, extensive border patrol agency called Frontex to patrol Europe's borders. ${ }^{18}$ Frontex's interdiction of migrants at sea and sending them back to their home countries has caused NGOs to accuse them of refoulement. ${ }^{19}$ Increasingly Western states have employed restrictive visa requirements, carrier sanctions, "safe third country" designations, "readmission agreements," and internal "safe zones" inside conflict areas to prevent migrants and refugees from crossing borders. ${ }^{20}$ While UNHCR has protested many of these measures, they can do little to stop them.

Due to increased restrictions on migration, controversies involving the rights of refugees and migrants have reached high courts throughout the world, including the U.S. Supreme Court, the High Court of Australia, and the European Court of Human Rights (ECtHR). ${ }^{21}$ These three courts have interpreted international refugee law differently in their jurisprudence, creating a discrepancy as to what non-refoulement actually requires. The U.S. and Australian courts have determined that state practices of interdicting mixed groups of migrants and refugees at sea do not violate non-refoulement. In 2011, the ECtHR determined that Italy's practices of interdiction at sea constituted non-refoulement, causing Italy and the EU to change their policies. These courts' interpretations of international refugee law will play a major role in creating international norms of treatment of

${ }^{17}$ See generally United Nations Office of the High Commissioner for Human Rights, Report of the detailed findings of the commission of inquiry on human rights in the Democratic People's Republic of Korea -A/HRC/25/CRP.1 (2014) (discussing China's policy of summarily repatriating escapees from North Korea).

${ }^{18}$ Frontex was authorized by (EC) 2007/2004. Frontex became operational on October 3,2005 .

${ }^{19}$ See, e.g., "NGO Statement on International Protection: The High Commissioner's Dialogue on Protection Challenges," UNHCR ExCom Standing Committee, $41^{\text {st }}$ Meeting, March 4-6, 2008. On interdiction at sea and refoulement, see Jill Goldenziel, When Law Migrates: Refugees in Comparative International Law, in PAUL STEPHAN, EDS., COMPARATIVE INTERNATIONAL LAW (forthcoming, Oxford University Press, 2015).

20 Deborah Anker, Joan Fitzpatrick \& Andrew Shacknove, Crisis and Cure: A Reply to Hathaway/Neve and Schuck, 11 HARV. HuM. RTS. J. 295 (1998), at 297.

${ }^{21}$ See, e.g., Sale v. Haitian Centers Council, 509 U.S. 155 (1993); Ruddock v. Vadarlis (2001) FCA 1329 (Federal Court) (Austl.); Hirsi Jamaa and Others v. Italy, 2012 Eur. Ct. H.R.; M.S.S. v. Belgium and Greece, 2011 Eur. Ct. H.R. For discussion of these cases, see Jill Goldenziel, When Law Migrates: Refugees in Comparative International Law in PAUL STEPHAN ET AL., COMPARATIVE INTERNATIONAL LAW (forthcoming 2016). 
refugee and migrants, and in shaping the refugee and asylum law of many states. As courts develop disparate interpretations of international refugee law relating to mixed migration, desperate individuals and sovereign states alike need the clarity that a Displaced Persons Convention can provide.

Despite its drafters' intentions to create a Convention that is universal in its application to all refugees, international refugee law is hardly applied universally. While human rights were a paramount concern when the treaty was negotiated, power politics have intervened throughout the development of international refugee law. Today, UNHCR primarily assists migrants who impact the security interests of the wealthier states who fund its operations, regardless of their status under international law. Meanwhile, many of these same wealthy states have increasingly restricted entry to refugees using tactics that may violate the Convention. New international law is needed to provide refugees with the human rights protections that the Convention's drafters intended, to protect the human rights of migrants who are not refugees, and to protect the rights of sovereign states.

\section{The Theoretical Groundwork fOR A New Displaced Persons CONVENTION}

As James Hathaway has noted, refugee status has always taken on "different meanings as required by the nature and scope of the dilemma prompting involuntary migration. ${ }^{, 22}$ But even as the scope of involuntary migration has radically changed over the course of the past sixty years, refugee status in international law has remained stagnant. As noted above, scholars and policymakers have repeatedly argued that international refugee law is irrelevant to the world we now face.

How can international law better protect the human rights of refugees and migrants while also protecting states? Great debate exists over exactly how to reform international law protecting those fleeing violence and persecution. Roughly speaking, proposals to reform international refugee law have been either moral or economic in nature. Michael Walzer and Niraj Nathwani, for example, have argued that assistance to refugees should be based on need. ${ }^{23}$ The moral obligation to assist people based on need rather than on persecution on the basis of particular categories, they argue, is equivalent, and therefore the category of "refugee" should expand

\footnotetext{
22 James C. Hathaway, The Evolution of Refugee Status in International Law: 19201950, 33 INT. COMP. LAW Q. 348 (1984), at 380.

${ }^{23}$ Michael Walzer, Spheres of Justice: A Defense of Pluralism and EQuality (1983); NiRAJ NATHWANI, RETHINKING REFUGEe LAW (2003), at 7.
} 
beyond the narrow Convention definition to all people forced to migrate and in humanitarian need.

Other scholars have called for a broadening of the definition of the term refugee. Joseph Carens argues that, from a moral perspective, the Convention definition should be revised so that "the seriousness of the danger and the extent of the risk, not the source of the threat or the motivation behind it," matters most. Selya Benhabib argues that Kant's "universal right to hospitality" imposes upon states a moral duty to assist anyone "whose life, limb, and well-being" are endangered, implying the need for a broader definition of the term "refugee." 24

Most broadly, liberal and utilitarian theorists argue that states are not only required not to refoul those who would have their lives endangered, but that they are obligated to accept larger numbers of refugees and immigrants. These theorists often conflate these categories, since they usually do not use the term refugee in the legal sense. Joseph Carens and Anne Dummet, for example, argue that liberalism requires that states recognize a right to freedom of movement that would require them to accept all those who wish to live there. ${ }^{25}$ Peter and Renata Singer argue that liberal democracies are obligated to accept refugees up until the point that tolerance in the society would break down, endangering peace and security. $^{26}$

Economic proposals to reform the 1951 Convention, by contrast, focus on the burden-shifting necessary to align state interests with greater international protection. While the details of these proposals vary significantly, most scholars agree that they must focus on burden-sharing and outcome-based solutions that focus on refugee assistance as it exists, not on the Convention definition of refugee. ${ }^{27}$ Two of the most prominent proposals, developed in the late 1990s by James Hathaway and Alexander Neve, and by Peter Schuck, argued for insurance-like schemes to incentivize Northern states to reduce the costs of processing migrants by shifting funds and transferring refugees to Southern states that would serve

24 Selya Benhabib, The Rights of Others: Aliens, Residents, and Citizens (2004), at 37.

${ }^{25}$ Joseph Carens, Migration and Morality: A Liberal Egalitarian Perspective, in Brian Barry and Robert Goodin, eds., FreE Movement: ETHICAL ISSUES IN THE Transnational Migration of PeOPle And Money (1992), at 25-47; Anne Dummett, The Transnational Migration of People Seen from within a Natural Law Tradition, in Brian Barry and Robert Goodin, eds., FREE MOVEMENT: ETHICAL ISSUES IN THE Transnational Migration of PEOPLE AND Money (1992), 169-80.

${ }^{26}$ Peter Singer and Renata Singer, The Ethics of Refugee Policy, in Mark Gibney, ed., Open Borders? Closed Societies?: The ETHICAL AND Political Issues (1988), at 111 30.

\footnotetext{
${ }^{27}$ See HATHAWAY, id.
} 
as host countries. ${ }^{28}$

As Hathaway later acknowledged, these proposals attracted little attention from policymakers and were roundly criticized by scholars. ${ }^{29}$ Among other flaws, scholars charged that the proposals accepted the current policies of Northern states to dodge the obligation of non-refoulement. ${ }^{30}$ The proposals suggested that refugees primarily be hosted in the global South, with Northern states providing funding to assist them there. Without a binding commitment by Northern states, critics argued that Northern states would relinquish their promised assistance fail absent a pressing refugee emergency affecting their own interests. Scholars also charged that the proposals failed to solve many flaws inherent to the current refugee regime, and that they promoted group-based rather than individualized processing for refugees, which would raise human rights concerns. Scholars also expressed concern that an insurance scheme risked commodification of refugees. $^{31}$

Recognizing the problem of population displacement beyond the plight of 1951 Convention Refugees, some countries have made regional agreements to address these issues. These efforts have largely failed. The 1969 OAU Refugee Convention and 1984 Cartagena Declaration for Refugees in Latin America expand the definition of refugee to include people who have fled violent conditions or disturbances in public order. ${ }^{32}$ However, documents are non-binding, states have been slow to incorporate them into their domestic law, and they include no burden-sharing mechanisms. EU Directives, most recently a set of 2011 Directives, are largely focused on curbing migration, although they do allow for "subsidiary protection" for people fleeing generalized conditions of violence who do not qualify for refugee status. ${ }^{33}$ Even before the EU's common asylum regime broke down in 2015, caselaw showed that EU states were not following the directives, and many states had opted out of the 2011 Directive. Temporary Protection (TP) regimes have been adopted

28 James C. Hathaway \& R. Alexander Neve, Making International Refugee Law Relevant Again: A Proposal for Collectivized and Solution-Oriented Protection, 10 HARV. Hum. RTS. J. 115 (1997); Peter H. Schuck, Refugee Burden-Sharing: A Modest Proposal, 22 YALE J. INT'L. L. 243 (1997).

${ }^{29}$ James C. Hathaway, Book Review: Rethinking Refugee Law, by Niraj Nathwani, 98 AM. J. INT'L L. 616 (2004), at 616.

${ }^{30}$ For the most prominent and thorough critique, see Anker, et al., supra note 20.

${ }^{31} I$. .

${ }^{32}$ See, e.g., Organization for African Unity (OAU), Convention Governing the Specific Aspects of Refugee Problems in Africa, Sept. 10, 1969, 1001 U.N.T.S. 45; Cartagena Declaration on Refugees, Colloquium on the International Protection of Refugees in Central America, Mexico and Panama, 22 November 1984.

${ }^{33}$ EU Directive 2011/95/EU. 
by some states in response to humanitarian emergencies. ${ }^{34}$ However, TP regimes are applied haphazardly, sow confusion by differing from state to state, and arguably have been used by countries to avoid their obligations under the 1951 Convention. ${ }^{35}$

None of these documents address the root causes of modern population displacement that has threatened international peace and security. The agreements are undermined because refugee emergencies often arise from conflicts between neighbors, complicating regional solutions. Moreover, the protections associated with all of these documents are ambiguous. Key terms are undefined, states lack will, capacity, or funding to implement them. Such non-binding regional agreements may clash with the universal aims of the 1951 Convention, sowing still more confusion as to whom is protected and how.

\section{A. Why International Law?}

What is the role of international refugee law in a modern migration environment at all? When proposing reforms for international law regarding people fleeing persecution and violence, this foundational question is necessary to consider. After all, senior officials in UNHCR, including the High Commissioner, have found that politically palatable solutions to displacement crises are often policy-based and not legal. ${ }^{36}$ As explained previously, most people flee persecution and violence into developing countries, where adherence to international law, and international human rights law in particular, may be weak. In states averse to international law, UNHCR often finds that pushing states to comply with international legal obligations does not work, and it needs to find other ways to assist refugees. As senior UNHCR officials explained to me, solutions are most easily found through bilateral negotiations for aid between donor and recipient states, or by emphasizing the humanitarian nature of a situation instead of legal commitments. ${ }^{37}$

\footnotetext{
${ }^{34}$ In the EU, regimes granting forms of temporary protection are called "subsidiary protection" or "humanitarian protection." See id.

35 Joan Fitzpatrick, Temporary Protection of Refugees: Elements of a Formalized Regime, 94 AM. J. INT'L L., 279, at 298; European Council of Refugees and Exiles, Position of the European Council on Refugees and Exiles on Temporary Protection in the context of the Need for a Supplementary Refugee Definition, available at http://ww.ecre.org.

${ }^{36}$ Interview with Antonio Gutierres, High Comm'r, UNHCR, in Geneva, Switz. (July $30,2010)$.

${ }^{37}$ Interview with Jose Riera, supra note XX; Interview with Antonio Gutierres, id., Interview with Dag Sigurdson, Deputy Head, Donor Relations \& Resource Mobilization
} 
However, international law to protect refugees and people fleeing violent conflict is still necessary. International law solves collective action problems that are important for the protection of both human rights and state security. A binding, international legal mechanism is necessary to keep states from adopting policies that collectively harm those displaced by persecution and violence, and from shirking their obligations to protect the human rights and assist other states. International refugee law provides a floor for state migration policies. Eric Posner and Adam Cox have recognized, in their discussion of an optimal migration contract, that refugee rights require international cooperation to avoid a "race to the bottom," in which states adopt increasingly restrictive refugee policies to deflect refugees to other states. ${ }^{38}$ Only international law can ensure that these refugees have somewhere to turn.

Moreover, for all of its failings, the Convention does provide legal protection to many people in need. The Convention serves as the basis for asylum law in many states - an important step toward harmonizing global refugee protections. Many of these states grant refugees most of the protections delineated in the Convention. In states that have signed the Convention but have weaker legal systems or fewer resources, UNHCR uses the Convention as a basis for its operations, and as a starting point for negotiations on what it can do to protect people displaced by persecution and violence. As Deputy Representative in Egypt, Katharina Lumpp explained to me, the Convention serves as a basis for negotiation on the treatment of refugees in state signatories. ${ }^{39}$ In state parties to the treaty, international refugee law provides a floor for refugee protection, and a baseline for negotiation to improve it.

On a broader level, international human rights law, including international refugee law, has always served an important aspirational purpose. Although most of the world's states are signatories to either the International Covenant on Civil and Political Rights and/or the International Covenant on Economic and Social Rights - which are known, along with the Universal Declaration of Human Rights, as the International Bill of Rights - no signatory truly lives up to all of the commitments it has made in either document. ${ }^{40}$ The rights that these documents seek to entrench are so broad and so vague that no signatory can possibly live up to the ideals they

Unit, UNHCR, in Geneva, Switz. (Jul. 21, 2010).

${ }^{38}$ Adam Cox and Eric Posner, The Rights of Migrants: An Optimal Contract, 84 N.Y.U. L. REv. 1403,1462; see also Ryan Bubb, Michael Kremer, and David I. Levine, The Economics of International Refugee Law, 40 J. LEG. STUD. 367-404 (2011) (describing a race to the bottom).

${ }^{39}$ Interview with Katharina Lumpp, Deputy Representative, UNHCR-Cairo, in Cairo, Egypt (Dec. 10, 2009).

${ }^{40}$ See generally ERIC POSNER, THE Twilight OF HUMAN Rights LAw (2014). 
contain, and full realization of these rights would also be impossible due to inevitable clashes between the ideals they embody. Yet these documents provide important aspirational norms for states, which commit to each other, in an international forum that they will keep trying to live up to these utopian standards. Indeed, these documents contain clauses that commit developing states to continued improvement toward these ideals, even if they cannot currently comply with them. So long as states continue to aspire to these international norms, they will continue to seek justice and human rights for all of their citizens. Much like constitutional law on the domestic level, international human rights law serves to entrench certain precommitments that cannot be violated, regardless of majority will. ${ }^{41}$ As states increasingly adopt international human rights law as a basis for their own constitutional instruments, enabling litigation and interpretation of these norms in domestic courts, their importance as foundations of law continue to increase.

International refugee law reinforces other normative goals of the international human rights system. The Genocide Convention, Convention on the Elimination of Racial Discrimination (CERD), and Convention Against Torture and Other Cruel, Inhuman or Degrading Treatment or Punishment (CAT), all proscribe categories of behavior related to those in the 1951 Convention. The International Bill of Rights also contains provisions entrenching an international human right to freedom of expression, which includes the right to express political opinions without persecution. ${ }^{42}$ The existence of refugees is often a sign that serious human rights abuses are occurring within a state, such as genocide or ethnic cleansing. Multiple international human rights commitments are mutually reinforcing and help ensure that states will be continually vigilant against human rights abuses.

\section{B. Why the 1951 Convention Definition of "Refugee" Must be Preserved}

The 1951 Refugee Convention, and the definition of "refugee" it contains, should not be modified. As an instrument of international human rights law, the core commitments entrenched in international refugee law remain as relevant and important as ever. ${ }^{43}$ The historical record shows that

\footnotetext{
${ }^{41}$ On parallels between international and constitutional law, see Jack Goldsmith \& Daryl Levinson, Law for States: International Law, Constitutional Law, Public Law, HARV. LAW REV. 1791-1868 (2009).

${ }^{42}$ ICCPR Article 19.

${ }^{43}$ On the relationship between international refugee law and human rights law, see generally Jill Goldenziel, The Curse of the Nation-State: Refugees, Migration, and Security
} 
members of racial, religious and ethnic minority groups have always been subject to persecution on the basis of these characteristics. We need only look at the news to see that such persecution is still rampant. Protection of people on the basis of these categories is worth preserving, as states have repeatedly been incapable of providing protections for individual members of these groups. Persecution of minorities is often systematic and not easily solved. International refugee law provides that these people must be given basic human rights even when their countries of origin cannot provide them; and that a certain minimum level of human rights, indeed, normatively exists outside the construct of states. International refugee law is truly international: law that extends beyond the traditional zone of state sovereignty. The Refugee Convention obligates states to provide legal protections for non-citizens who are de facto without the protections of their countries of origin, presenting a stark exception to a state's sovereign right to control who enters and leaves its territory.

For anyone concerned with international human rights, international refugee law thus provides critical legal and moral functions for protecting the rights of those whom the international community has deemed the most vulnerable: members of religious, racial, and ethnic minorities, as well as members of particular social groups, such as homosexuals. Even as categories of those persecuted on the basis of political opinion has changed over time, the international community has, on a normative level, always been concerned with the protection of minority rights. As the protection of minority rights is fundamental to democratic systems, any international legal system seriously concerned with democratic values must protect them as well.

To understand why refugees are distinct from other groups of migrants and therefore merit different legal protections, we must consider how human rights operate under a general theory of state sovereignty. Any discussion of international legal theory based on sovereignty is, of course, neither perfect nor fully descriptive of the reality of international politics. My analysis will proceed given these caveats, while acknowledging that sovereignty remains the basis of most theories of international law and international relations, and the starting point for most theoretical scholarship on international human rights law.

1. Refugees Have Unique Legal Claims for Protection

Refugees are distinct from most other migrants because they are in International Law, __ ARIZ. ST. L.J. _ (forthcoming 2016). 
unable to avail themselves of the protection of their states due to their fear of persecution. Assuming a system of sovereign states, pursuant to international human rights law, states have the legal and moral responsibility to protect the rights of their citizens. States and individuals can then rely on this social contract. States sever this contract with refugees when they are unable to protect their citizens from persecution or a wellfounded fear of it. ${ }^{44}$

Unlike refugees, other migrants do not have their ties to their states severed. Other migrants, such as those leaving their countries due to economic woes, generalized violence, or climate change, may have a government that is very much interested in providing them with legal protections. ${ }^{45}$ Moreover, whether displaced inside or outside their country, migrants who are not refugees enjoy benefits of citizenship that refugees cannot. Migrants have freedom to travel and freedom of movement, which bona fide refugees do not have. Internally Displaced People (IDPs) may be able to migrate to other sections of their country, where they can enjoy these protections, without moving abroad. ${ }^{46}$ Refugees are unlike other migrants precisely because of their inability to enjoy the benefits of citizenship due to their fear of persecution, and their individualized, specific needs demand a specific solution.

Refugees require legal complementarity: legal protections ordinarily provided by states because states are unavailable to provide these basic needs. Historically, a primary function of international refugee law was to provide refugees with passports, travel documents, and certifications of personal status that states were unable to provide them. Although UNHCR today is more an international humanitarian agency than a legal one, these basic legal protections remain among its most critical functions. Refugees

${ }^{44}$ Refugees may also be stateless, citizens of no state. Statelessness gives rise to another host of international legal problems outside the scope of this article. Statelessness is addressed by another international instrument, the 1961 Convention on the Reduction of Statelessness.

45 On proposals to assist climate change migrants, see Katrina Miriam Wyman, Responses to Climate Migration, 37 HARV. ENVTL. L. REV. 167 (2013) (discussing three recent proposals for international legal and non-legal responses to climate change migration); Agnes Hurwitz, Climate-Related Displacement: The Perilous Path Towards Normative Development, in Susan Akram and Tom Syring, eds., STILL WAITING FOR TOMORROW: THE LAW AND POLITICS OF UNRESOLVED REFUGEE CRISES (2014).

46 The "Deng Principles" on internal displacement have been developed to provide an international framework for protecting IDPs. However, these principles are not binding and are left to individual states to adopt in their own policies and caselaw, and do not address the root causes of displacement that may cause both internal and external displacement. See Guiding Principles on Internal Displacement, UNITED NATIONS OFFICE FOR THE COORDINATION OF HUMANITARIAN AFFAIRS, (2004), available at https://docs.unocha.org/sites/dms/Documents/GuidingPrinciplesDispl.pdf. 
also need the right to work and access justice required by international refugee law, because their states are unavailable to provide them with these basic needs. As mentioned above, other types of migrants can, at least theoretically, still avail themselves of the protections of their states.

Unlike most people fleeing war, poverty, or natural disasters, a refugee's status may never end. ${ }^{47}$ For those fleeing war, resolution of conflict within the state, or recovery from the natural disaster that caused their displacement, may end their displacement. Their displaced status depends on the resolution of the conflict within the state. Some refugees may be able to repatriate if the circumstances causing their fear of persecution subside. But for many refugees, this will never happen. The nature of the persecution that caused the flight is dependent on both nature of the state and the individual involved. Resolution of conflict or disaster within the state may never be enough for the bona fide refugee. Just as it would have been ludicrous to expect all Jews to return to Germany after the end of World War II, it would be abhorrent to expect all refugees who have fled persecution to return to their countries of origin.

\section{Refugees Have Unique Moral Claims for Protection}

Beyond the gruesome history and persistence of persecution in international law, because of their political and legal vulnerability, refugees have the strong moral claims for international assistance that other groups of migrants do not. Unlike refugees, economic migrants are likely to be protected by their states. Most states ideally wish to prevent economic migration. Assuming states are rational economic actors, even those who benefit from remittances fear brain drain and would prefer to create economic opportunities at home rather than having citizens live and work abroad. Moreover, economic migration is largely voluntary. For these reasons, economic migrants have less of a moral claim for international protections than other groups of migrants.

Migrants fleeing violent conflict or climate change have a stronger moral claim to international protection than economic migrants. However, their situation is still distinct from that of refugees. These groups of migrants have governments that can seek domestic solutions or request international aid to assist them. South Sudan, for example, is a fragile state

\footnotetext{
${ }^{47}$ Of course, a climate change migrant's plight may never be fully solved if her land disappears. However, as discussed herein, climate change migrants are likely to receive assistance and protection from their own governments, while refugees will not. In a sense, climate change migrants can receive restitution for the loss of their land from their states or the international community. Refugees can never receive compensation for their status that will similarly make them whole.
} 
from which many have fled, but its government has sought international assistance for its people. ${ }^{48}$ The governments of climate change migrants, in particular, may be actively working toward a solution to protect their citizens. The Marshall Islands, to name one climate-change ravaged country, is currently seeking financial assistance to help its citizens who are affected by climate change. ${ }^{49}$ While the plight of such people is morally wrenching, their situations do not demand the same type of protection that refugees require. For these types of migrants, international aid may be available and appropriate for migrants as groups, based on the circumstances that collectively affect them. While all migrants should be treated in a manner that respects their human rights, their situations may not demand the individualized processing and treatment that international refugee law demands as part of the international human rights regime.

Refugees present the most morally serious case of need because of they face the world's most vulnerable legal and political circumstances. Persecution on the grounds enumerated in the 1951 Convention is among the most egregious of human rights abuses. Even if other groups of migrants have equivalent or greater material need to refugees, their situation could be solved by humanitarian aid alone. Morality does not require that law prioritize the needs of the most materially destitute migrants over the needs of refugees. Refugees need legal protections to meet their unique needs.

Changes in humanitarian needs over time also should not change the core definition of what constitutes a human right. The right of freedom from persecution on the basis of one's religious, racial, ethnic, or national status, or political opinion, is one that has been entrenched in international law before the advent of modern law itself. Expanding the category of "refugee" to include other groups of migrants would undermine the protections that states long ago determined to be in their moral and political interests, along with well-established law that has given legal protections to generations of people without anywhere else to turn. ${ }^{50}$

While sovereign states legitimately have the right to restrict their borders, this does not mean that states have no moral obligation to admit as many or as few applicants who would like to live there. States need morally grounded legal principles for whom to prioritize for entry. International refugee law provides states with a universal rubric for whom to give precedence. People who are persecuted on the basis of religion, race,

${ }^{48}$ See Fragile States Index, 2015, available at http://fsi.fundforpeace.org/rankings2015 (ranking South Sudan the highest among the world's most fragile states).

${ }^{49}$ Coral Davenport, The Marshall Islands Are Disappearing, N.Y. TIMES (Dec. 2, 2015).

${ }_{50}$ Joseph H. Carens, Refugees and the Limits of Obligation, PUBLIC AFF. Q. 31-44 (1992). 
nationality, or membership in a particular social group should be prioritized in the international system, legally and morally, because of their unique needs as well as the international community's moral obligation to protect those fleeing persecution.

\section{The Expressive Importance of Preserving the Refugee Definition}

International refugee law as it currently exists provides a powerful expressive function. By categorizing victims of persecution on the basis of race, religion, nationality, political opinion, or membership in a particular social group as needing international protection, the international community has effectively proscribed certain behaviors as beyond the pale of what it can accept. The term "refugee" holds tremendous rhetorical power. The term "migrant," standing alone, has no meaning in international law. ${ }^{51}$ It connotes mere movement of a person from one place to another due to any number of circumstances. "Refugee," by contrast, is a term that defines a specific set of commitments that the international community has historically owed to a specific type of international migrant. "Refugee" also connotes humanitarian need worthy of international assistance. The strategic use of these terms by actors in the international community can support or detract from their own political aims. A country cannot produce large numbers of "refugees" unless conditions inside it are unstable. Countries may also suffer reputation losses from expelling "refugees," or by failing to admit those who claim to be "refugees." Conversely, asylum countries are likely to gain reputational benefits from hosting "refugees." Defining a group of migrants as "refugees" also affects the way that other political actors will treat population movement.

The existence of the refugee status, as it currently stands, plays another important expressive role by implicitly condemning certain state behaviors. Refugee status connotes the failure of states to protect their own citizens; more particularly, the failure of governments to do so. Indeed, refugee status implies a human element that other types of forced migration do not. Refugees flee when states are involved in persecution or are unable or unwilling to protect individuals from persecution occurring within their borders. Other categories of migrants may be fleeing the vicissitudes of fortune, perhaps wrought by Mother Nature, but not necessarily due to state action. The existence of refugee law casts aspersion upon the behavior of states that fail to protect their own citizens, and more so in the case of states

\footnotetext{
51 "Migrant workers" who have jobs abroad, however, are defined and protected by The International Convention on the Protection of the Rights of All Migrant Workers and Their Families, U.N.G.A. 45/158 (1990).
} 
that are unwilling to do so. Such a basic failure of the function of a government calls the legitimacy of that state or government into question.

This expressive function is increasingly important in the context of recent international debates over when sovereignty can be violated to protect human rights, embodied by controversies over the Responsibility to Protect and appropriate uses of the International Criminal Court. ${ }^{52}$ The Security Council has linked the prevention of refugee flows and population displacement, considered a threat to international security, as justification for recent international interventions in Haiti, Iraq, Kosovo, Liberia, Rwanda, and Somalia. ${ }^{53}$ In the context of increased willingness by the international community to violate sovereignty to protect human rights, it is especially important not to back away from international refugee law, which has long guaranteed rights that individuals have independent of states. Having such a category in international law sends a message to states that the international community will not tolerate their persecution of religious and ethnic minorities and dissidents.

\section{The Need for a Displaced Persons Convention}

Do people fleeing violence deserve protection by states? Both moral and practical reasons suggest the answer is yes. The special obligation to protect refugees does not absolve states of a moral responsibility to legally protect or materially aid other people. On moral grounds, the philosophical principle of mutual aid requires that if a person is in dire need and a state is able to assist that person with little cost, a state has a moral duty to help them. ${ }^{54}$ Moral concerns are heightened when neighboring states bear some responsibility for the circumstances of displacement, such as international involvement in civil conflict.

Even for states who reject morality principles on sovereignty grounds, practicality mandates international assistance for people who fall outside of the Refugee Convention's definition of refugee. States benefit from stability and predictability in the international system, and suffer from having their borders flooded by those seeking to leave desperate circumstances elsewhere, whatever the cause of their flight. States also suffer when vulnerable people compete over scarce resources, often causing conflict that can spill over state borders. In our globalized world, violent

\footnotetext{
${ }^{52}$ See, e.g., Secretary General, ImPLEMENTING the Responsibility to Protect: REPORT OF THE SECRETARY-GENERAL (2009) A/63/677.

${ }^{53}$ Guy Goodwin-Gill, 'Editorial: Refugees and Security', INT’L J. REFugeE LAw, vol. 11, no. 1, 1999, 3; Alan Dowty \& Gil Loescher, Refugee Flows as Grounds for International Action, 21 INT. SECUR. 43-71 (1996), 39-40.

${ }^{54}$ WALZER, supra note 23, at 49-50.
} 
conflict has ramifications for population displacement throughout the globe. As of this writing, civil war has displaced at least 4 million Syrians in neighboring countries, but more than a million others have fled as far as Europe, Australia, and the U.S. Practicality demands international action, even when moral arguments fail.

Binding international law is needed to simultaneously protect both the interests of states and people who have fled internationally from violent conflict. Mere legal standards and best practices will not suffice given the scope of the problem. The international community must legally precommit to protect these people and help them retain their basic right to human dignity. Without binding law, states will likely have the incentive to shirk their duties when international politics dictate that they do so, due to domestic political constraints or failure of their immigration systems. International law also provides important guidance to the international community, even to non-signatory states, on how to manage population displacement. Currently, even in states that have not signed the Refugee Convention, UNHCR uses the Convention and state practice, along with states' other commitments to international human rights law, as leverage to pressure states to protect people fleeing violence and persecution. Moreover, the existence of international law reduces the possibility that assistance will be politicized in the future. With international agreement on how to protect people displaced by violence, and how they should be categorized, the international community will be less able to ignore these populations or to selectively aid them for political reasons.

Critics may scoff that international law cannot solve a problem that so acutely implicates state sovereignty. Recent events offer an instructive counterargument. Just twenty-five years ago, when the world was beginning to recognize signs of global warming, the idea of international cooperation to fix this global problem was nearly unthinkable. Yet in 2015, delegates from the world's nations unanimously agreed to a framework to combat climate change. Population displacement, too, is a problem of international scope and ramifications that demands an international solution. Persistent security and human rights concerns caused by population displacement may bring the world to commit to new international law. Urgency has already caused the E.U., countries neighboring Syria, Australia, and elsewhere to seek atomized legal solutions that can be globalized, harmonized, and improved. A U.N. Global Summit will consider legal and policy solutions to the global migration crisis in September 2016. 


\section{WHAT A DISPLACED PERSONS CONVENTION WOULD LOOK LIKE}

The goal of this section is not to draft a new international legal instrument. To do so would be naïve. Ultimately, all international law must be negotiated and bargained-for by states. No new international law can be expected to succeed without such negotiation by states and other stakeholders. This article's goal is simply to sketch some considerations for states as they negotiate new protections to protect people fleeing violent conflict while preserving their own sovereign aims and protecting their borders. A Displaced Persons Convention (DPC) must involve provisions for defining of the category of Displaced Persons, how DPC protections would be triggered and monitored, what rights Displaced Persons would receive, and state obligations. The article will discuss each of these in turn.

\section{A. Defining Displaced Persons}

State parties must negotiate the definition of "Displaced Persons" to ensure that the definition reflects concerns for both state sovereignty and human rights. A DPC should recognize that the global migration crisis includes three primary categories of people: refugees, economic migrants, and those fleeing violent conflict. Climate change migrants present a fourth category, which is already being addressed by other draft conventions and international commitments. ${ }^{55}$ Refugees should continue to receive unique protections under international law. Those seeking economic opportunity alone should be directed to a state's regular immigration system. A DPC would protect the third category, those fleeing violence but not persecution.

The legal definition of "Displaced Person" must be carefully circumscribed to avoid encompassing endless flows of people. I propose that the international community should protect only those Displaced Persons whose flight threatens international peace and security, in accordance with the language of Article I of the U.N. Charter. States will be interested in providing protection if international stability is threatened. While this standard is less stringent than the "well-founded fear" criterion in the Refugee Convention, it also ensures that every individual cannot have a claim to be a Displaced Person.

As a starting point for the definition of "Displaced Person," the international community might draw lessons from the definitions promulgated by the Organization for African Unity and the European Community in their attempts to provide protection to those who do not meet

\footnotetext{
${ }^{55}$ See supra note 45 .
} 
the Convention definition. The OAU Refugee Convention defines a "refugee" as: 56

every person who, owing to external aggression, occupation, foreign domination or events seriously disturbing public order in either part or the whole of his country of origin or nationality, is compelled to leave his place of habitual residence in order to seek refuge in another place outside his country of origin or nationality.

The 2011 EU Directive provides "subsidiary protection" to those who can show "substantial grounds . . . for believing that," if returned to his country of origin or former habitual residence, he "would face a real risk of suffering serious harm ... [and] is unable, or owing to such risk, unwilling to avail himself or herself of the protection in that country." defines "serious harm" as "(a) death penalty or execution; or (b) torture or inhuman or degrading treatment or punishment of an applicant in the country of origin; or (c) serious and individual threat to a civilian's life or person by reason of indiscriminate violence in situations of international or internal armed conflict." 58

Both definitions expand the category of persons who should receive international assistance in a way that would not create endless obligations for states. The OAU definition focuses on the causes of displacement, while the EU's definition centers on the risk of harm that an individual will face if refouled. The OAU's mention of "external" or "foreign" pressures implies that international involvement in a displacement logically is required for an international response to occur. The events must be "seriously disturbing public order," which is close to the level of threatening international peace and security. Moreover, Displaced Persons must be "compelled" to leave their place of habitual residence in order to seek refuge outside of his country. This standard, while less stringent than the specific fear of persecution required by the 1951 Convention, still demands that people are forced to migrate for reasons other than personal convenience, and would exclude economic migrants. "Compelled" implies that people find it necessary to flee their homes because their states cannot provide adequate protection in a particular instance. Combining this definition with the EC's requirements that a specific, individualized risk of harm restricts the

\footnotetext{
${ }^{56}$ Organization for African Unity, supra note 32.

${ }^{57}$ European Council Directive 2004/83, On Minimum Standards for the Qualification and Status of Third Country Nationals or Stateless Persons as Refugee or as Persons who Otherwise need International Protection and the Content of the Protection Granted, 2004 O.J. (L304) 12 (EC), art. 2(e).

${ }^{58}$ Id., Art. 15(a)-(c).
} 
definition further. Including the EC's criteria ensures that the focus of protection will be on individual Displaced Persons, rather than groups of displaced people.

The OAU and EC definitions, while imperfect, provide important guidance for protecting both individuals and states. No doubt, they will not satisfy those who seek to expand the category of refugee more broadly, as discussed above. However, put together, the OAU Convention and the EC Directive sketch out a definition of "Displaced Person" likely to be accepted by states. At the core of both is the norm of non-refoulement, the idea that a person must not be sent back to a place where her life would be endangered. Together, both documents protect individuals fleeing for reasons beyond the stringent standards of the 1951 Convention while ensuring that the definition of Displaced Person will not become so broad as to be meaningless and require international protection for anyone in need of humanitarian assistance. State practice, or at least the intent of states in Africa and Europe, lies behind these definitions as well. A broader commitment to a similar definition by states would not therefore result in a problematic rollback of international aid and legal protections from many who currently receive them. Given quickly changing migration flows, any definition of Displaced Persons should be revisited by states parties every few years, which would allow states to respond to new migration challenges facing states.

A DPC must also make clear whom it would not protect. It must state that Displaced Persons are not refugees, and that a DPC will not conflict with the Refugee Convention. Economic migrants, climate change migrants, and IDPs should be excluded, for reasons discussed above. An exclusion clause is necessary to ensure that states are not required to protect individuals that pose security threats. A DPC must also clarify that individuals will have the burden to prove that they meet the criteria set forth in the definition of "Displaced Person," and lay out individual status determination procedures for this to occur. To deter illegal entries, a DPC also should not protect those who enter a country illegally. The Refugee Convention forbids denial of refugee status to people who meet the relevant criteria who enter a country illegally, reflecting the urgency of flight from persecution and the moral imperative to protect refugees. A DPC need not morally require such a provision. Forbidding Displaced Person status to anyone who enters illegally could deter illegal migration, thereby making a DPC more appealing to states.

\section{B. Triggering Convention Protections}


A DPC must specify how convention protections would be triggered. Negotiating states may wish to consider one or several options. A DPC should be based on the principle of complementarity, providing legal protection to individuals only when their countries of origin are unable to provide it. Such a declaration of state incapacity might come from the state itself in a formal plea for international assistance, or by designation by the General Assembly or UNHCR that the state itself is incapable of providing for its citizens in a particular instance and that international assistance under the treaty is thereby required. The reputational costs of such a declaration of state incapacity would deter states from requesting international assistance unless it is necessary, and would incentive them to enact protections to avoid displacement in the first place.

Convention protections might also be triggered by numbers of people displaced by violent events, such as a mass influx of 1,000 per day over a short time, which is unofficially used as UNHCR's criteria for mass influxes of refugees now. Alternatively, it could be triggered by numbers of people from a given country who have registered for services from UNHCR, or by a vote of the Security Council, General Assembly, or Convention signatory states that would determine whether a particular group of people met the definition of Displaced Persons. The voices of Displaced Persons themselves, as well as NGOs and other stakeholders, should also be considered in this process. Unlike its current practice, UNHCR must be required to publicize numbers of people registering for its services at various field offices so that the international community can become easily aware of flows of displaced people and act on them.

Despite its flaws, UNHCR is best positioned to supervise a DPC. The agency has, de facto, been providing for the needs of much of this population for years, so it has the expertise and the capacity to expand its operations to provide aid and administer new international law. Providing UNHCR with core funding for humanitarian use would insulate the agency's activities from some of the politicization inherent in past humanitarian actions to assist refugees. With funding at the ready, the mandate to administer new international law, and a reaffirmation of its legal protection functions, UNHCR could more expeditiously assist both refugees and Displaced Persons. It would no longer have to wait to act until it received U.N. authorization or funding from a politically interested donor state.

\section{Rights of Displaced Persons}

Because they are morally and politically distinct from refugees, the international community has a different set of obligations to Displaced 
Persons. According to UNHCR, refugee status terminates via one of three durable solutions: local integration, resettlement, or repatriation. Article 34 of the Refugee Convention encourages states to "facilitate the assimilation and naturalization of refugees," although it stops short of requiring this. By contrast, protections for Displaced Persons under a DPC should be geared toward eventual repatriation.

Accordingly, Displaced Persons should only be granted temporary protection until sufficient arrangements can be made for them to return to their homes or to a safe zone within their country of origin. They should know that temporary protection can be revoked any time, with reasonable notice. Unlike refugees, Displaced Persons should not have access to thirdcountry resettlement. "Local integration" means something different in each country, but Displaced Persons should be integrated only to the extent that they can easily be repatriated when the situation in their origin country stabilizes.

Beyond basic shelter and sustenance and jus cogens human rights protections, states must negotiate what obligations to Displaced Persons they can realistically provide as an international community. Ideally, states would ensure that all Displaced Persons enjoy all of the inalienable human rights delineated in the body of international human rights law. But doing so is politically unrealistic. ${ }^{59}$ All states must respect the human rights of Displaced Persons, and a DPC should be viewed as an instrument of international human rights law. However, a DPC should not look like other human rights treaties, such as the ICCPR or the Refugee Convention, with long lists of aspirational rights commitments that no state can truly live up to, and no true enforcement mechanisms. Unlike other human rights treaties, a DPC must require coordinated state action to solve displacement crises, specify how it would work, and provide enforcement mechanisms. This will also make a DPC more likely to be effective than other human rights treaties.

DPC States must negotiate a floor of obligations that they can universally provide to Displaced Persons, recognizing that no one-size-fitsall solution exists for all states, nor all groups of Displaced Persons. For example, requiring that all Displaced Persons be granted work permits might be infeasible in countries with nearly $25 \%$ unemployment, such as Greece. For similar reasons, a DPC might not include the "right to work" language listed in the Refugee Convention and other human rights instruments. Instead, a DPC could require that signatory states convene to promote and fund creative solutions for Displaced Persons to have livelihoods when DPC protections are triggered. To treat Displaced Persons

${ }^{59}$ See generally POSNER, supra note 40. 
humanely, a DPC must make clear what obligations states have to Displaced Persons, and must be realistic about these obligations. All people must be able to make informed choices about the rights and opportunities they will have if they flee their countries.

\section{State Obligations}

1. Burden Sharing: Funding and Hosting

The success of a DPC will hinge on provisions for burden sharing among states. ${ }^{60}$ The term "burden-sharing," which is often used when discussing humanitarian aid, encompasses two distinct concepts when dealing with refugees and Displaced Persons: hosting and financial assistance. Hosting of most Displaced Persons will, de facto, occur in the less developed states where most already reside. These states will be responsible for ensuring non-refoulement and for providing Displaced Persons with basic needs and sustenance while they are present. More developed states must also host Displaced Persons who reach their borders, as well as ensuring their protection in any third countries where they might redirect Displaced Persons. Wealthier and poorer states alike will be responsible for preventing the root causes of displacement and for ensuring the physical safety and human rights of Displaced Persons if and while repatriation occurs. A DPC must clarify the hosting responsibilities of wealthier and poorer states.

A DPC must also include provisions for financial assistance for states hosting refugees. A DPC must ensure that poorer states hosting refugees can rely on financial and technical assistance from wealthier states. Most Displaced Persons are already in the developing world. Providing temporary protection to Displaced Persons within their region of displacement will often be the most practical possibility. Linguistic and cultural similarities can help Displaced Persons integrate in their host communities, and regional economic cooperation may allow those displaced to engage in productive economic activities. Geographic proximity can also facilitate ties between Displaced Persons and their countries of origin, which will facilitate eventual repatriation. Providing physical security and access to healthcare, housing, courts, and other state infrastructure will be expensive, and developing nations usually cannot bear these costs alone.

\footnotetext{
${ }^{60}$ Burden-sharing has been a frequent theme of the High Commissioner's annual dialogues. For recent discussions, see United Nations High Commissioner for Refugees, International Cooperation to Share Burden and Responsibilities, June 2011, available at: http://www.refworld.org/docid/4e533bc02.html.
} 
Financial assistance from wealthier to poorer states to help Displaced Persons will likely be appropriate. Poorer states, however, will be unlikely to sign a DPC that lets wealthy states host no Displaced Persons. Less developed states need assurance that increasing numbers of Displaced Persons will receive temporary protection in wealthier states if poorer states become overwhelmed, or if repatriation remains impossible after a protracted period. Poorer states will also want to ensure that wealthier states will help them transfer Displaced Persons if a mass influx would exacerbate ethnic tensions or otherwise threaten domestic security. A DPC must commit both all parties to host Displaced Persons, and all parties to cooperate to implement the financial and technical assistance necessary to implement mechanisms for providing humanitarian aid and protecting human rights.

The U.N.'s own best humanitarian practices dictate that a common pool of humanitarian aid money should be created and reserved for deployment in emergency situations. States could commit to contribute to an international fund for Displaced Persons, similar to the fund underlying the Global Counterterrorism Forum, or funds for many international environmental protection initiatives. Countries would be required to commit regularly, not just in times of emergencies, based on their funding commitments to the U.N. or other agreed-upon criteria. UNHCR or another supervisory body could administer the fund to provide protection and assistance for Displaced Persons. This commitment would help rectify the funding gap that has been identified as a weakness in other proposals to assist people displaced by violence. ${ }^{61}$

Both wealthier and poorer states would be incentivized to participate in a DPC with burden sharing provisions attached. All states benefit from predictability and stability in the international system. All states have the incentive to avoid the instability and potential for conflict spillover that accompanies massive flows of people fleeing violence. A burden-sharing scheme would be expensive. However, the costs to wealthier countries of a new DPC may well be less than the current strains on their asylum processing and security systems. It might also be more sustainable than existing migration deterrence mechanisms by wealthier states, which are increasingly costly and obviously not working well. Economic analysis is needed to determine this, as well as what would constitute situationspecific, adequate financial compensation for poor countries hosting refugees. Poor states would benefit from the assurance that they will receive assistance when overwhelmed by an influx of Displaced Persons. A DPC would not prevent states from pursuing their own foreign policy objectives,

\footnotetext{
${ }^{61}$ See supra note 45.
} 
such as giving additional development aid to their allies. However, a common fund would provide baseline financial assistance and a minimum commitment to burden sharing. UNHCR would likely welcome a DPC with funding attached because it would save them from needing to undergo complicated legal and administrative contortions to protect large "mixed flows" containing people fleeing both violence and persecution. It would also provide them grounds to negotiate with governments for greater international protections for Displaced Persons.

A more complete discussion of burden-sharing mechanisms lies beyond the scope of this paper. In short, states must negotiate how costs should be allocated, weighing tradeoffs between hosting and financial commitments. Enforcement of burden sharing mechanisms will be critical to the success or failure of a DPC.

\section{Preventative Measures}

Population displacement will not end until its root causes are addressed. A DPC, therefore, should require states to implement preventative measures in order to receive a guarantee of future international assistance. States cannot necessarily predict that their countries will erupt in civil conflict. However, they can tell if they are situated in a bad neighborhood, where surrounding states are prone to instability and strife. States in the global North can often predict whether and how such issues will affect their borders, on the basis of how past episodes of international violence have impacted their immigration and border controls. A DPC could pre-commit states to responding to these future needs. It could also commit states to allowing the international community to establish safe zones for refugees and forced migrants, within their borders, in the event of civil conflict. Safe zones accessible for provision of legal and humanitarian assistance could help stem the flow of Displaced Persons elsewhere. A DPC could also ensure that peace treaties to which states are parties or help negotiate will include provisions for safe return of refugees and Displaced Persons. The treaty should also stipulate reporting mechanisms to allow the international community to plan for displacement before it occurs.

The Convention should also commit states to allow an international body to implement an information campaign designed to avoid misconceptions about who qualifies as a Displaced Person, and the assistance and protection that Displaced Persons will receive. In the late 1980s, as part of the Comprehensive Plan of Action to end the Indochinese boatpeople crisis, UNHCR set up an information campaign on television in Vietnam. The advertisements showed scenes of adequate, but not deluxe, refugee camps in Hong Kong and elsewhere, and featured interviews with 
UNHCR personnel discussing the refugee status determination process, and explaining how those who did not qualify would be sent back to Vietnam. The advertisements were designed to present Vietnamese people with neutral facts that would enable them to make an informed decision about whether to leave their country. The ads are credited with wildly reducing flows of "boat people" from both North and South Vietnam. ${ }^{62}$ Similar information campaigns might be useful in reducing flows of migrants to Europe and elsewhere today.

\section{Supplementing Refugee Protections}

All states participating in a DPC should be required to ratify the 1951 Convention and its basic norm of non-refoulement. This would shore up protection for refugees by nations in the world who have an interest in receiving hosting assistance but who have previously been reluctant to sign the 1951 Convention. It would also ensure that international organizations and domestic legal systems alike are forced to understand the two separate categories of refugees and Displaced Persons and the differing protections that they will receive. Having the Refugee Convention as a prerequisite for a DPC will ensure that the two documents are viewed as complementary, and that countries do not lump Displaced Persons and refugees together into one larger category that would undermine protections for both.

\section{CONCLUSION}

The reforms proposed here would improve protections for refugees, Displaced Persons, and states alike. The improved doctrinal clarity would provide guidance to shape the behavior of states, individuals, U.N. Agencies, and NGOs within the international system while providing a stronger legal framework for the provision of humanitarian aid by the international community to those in need. It would make clear that persecution on the basis of religion, race, nationality, or membership in a particular social group is still among the most heinous of international crimes. Clarification that Convention refugees will receive priority in the international system for resettlement and assistance would reduce the processing burden on states and on UNHCR by discouraging people who do not meet these categories from applying. Those who still find it necessary to flee but who do not meet Convention grounds can be assured that they will receive temporary protection, and not summarily refouled to dire

${ }^{62}$ See generally Luise Druke, InNovations in Refugee Protection, 1St Ed. (2014); AlEXANDER CASElla, BREAKING THE Rules (2011). 
circumstances. States can be assured that they will have some control over who will reach their borders and to whom they will have to provide humanitarian aid, and a commitment to participate in a DPC will also enable states to plan to mitigate future displacement issues.

This solution, of course, will not solve all of the problems faced by refugees, Displaced Persons, and the states where they flee. Desperate people will always flee desperate circumstances. Hard and heart-wrenching cases will abound. Some politicization of the regime is inevitable; states providing oversight to a displacement regime may still decide to provide assistance to some people and not others on political grounds. The analysis above is necessarily state-centric and does not capture the complex role that non-state actors and stakeholders - violent humanitarian, and otherwiseplay in creating and managing population displacement. The international community must carefully design a DPC to reduce pull factors and an undue burden upon states. However, doctrinal clarity will help circumscribe the burdens on states and also clarify which migrants will receive international assistance and which others would be better off seeking alternatives to flight abroad.

Many of the legal and policy solutions discussed here could help improve international protections for refugees as well as Displaced Persons. But the two groups must not be lumped together for purposes of protection and assistance. The international community cannot roll back or water down existing legal protections for refugees by expanding the definition of "refugee" because the core values that the refugee regime protects are too important and foundational to our very conception of what international human rights is. If every person fleeing violence were a refugee, as other commentators would have it, then protection of bona fide refugees, and minority protections that are fundamental to our human rights regime, would be lost. Put simply, if everyone is a refugee, than no one is.

Yet no longer can international law turn a blind eye to the plight of those displaced by war and other violent conflict. Both human rights and international security face dire harm from states' erratic and inconsistent response to a growing crisis. A Displaced Persons Convention offers one modest solution. 